Огляди літератури, оригінальні дослідження, погляд на проблему, ювілеї УДК 616.36-003.826:616.24-007.272]-008.9-092-036108

DOI 10.11603/1811-2471.2019.v0.i1.10067

\title{
ВПЛИВ ДЕФІЦИТУ ГІДРОГЕНУ СУЛЬФІДУ НА ПАТОГЕНЕТИЧНІ МЕХАНІЗМИ ПРОГРЕСУВАННЯ ХРОНІЧНОГО ОБСТРУКТИВНОГО ЗАХВОРЮВАННЯ ЛЕГЕНЬ ТА НЕАЛКОГОЛЬНОГО СТЕАТОГЕПАТИТУ НА ТЛІ ОЖИРІННЯ
}

\author{
๑О. С. Хухліна, О.Є. Гринюк, О. Є. Мандрик, О. В. Каушанська, В. С. Смандич \\ ВДНЗ України «Буковинський державний медичний університет»
}

РЕзЮмЕ. Комплексні дослідження гомеостазу гідрогену сульфіду $\left(\mathrm{H}_{2} \mathrm{~S}\right)$ можуть відкрити нові механізми взаємообтяження хронічного обструктивного захворювання легень (ХОЗЛ) та неалкогольного стеатогепатиту (НАCГ).

Мета - встановити роль $\mathrm{H}_{2} \mathrm{~S}$ у механізмах прогресування ХОЗЛ та НАСГ на тлі ожиріння.

Матеріал і методи. Обстежено 100 хворих на ХОЗЛ, у тому числі 49 із НАСГ та ожирінням I ступеня: 1 група 28 пацієнтів із ХОЗЛ (2B GOLD); 2 група - 23 хворих на ХОЗЛ (3C, D); 3 група - 25 пацієнтів із ХОЗЛ (2B) із НАСГ; 4 група - 24 хворих на ХОЗЛ (3C, D) із НАСГ; контрольна група - 20 практично здорових осіб (ПЗО).

Результати. Вміст у крові $\mathrm{H}_{2} \mathrm{~S}$ у ПЗО склав $(75,3 \pm 3,2)$ мкмоль/л. У хворих усіх груп вміст у крові $\mathrm{H}_{2} \mathrm{~S} 6$ бв знижений: у хворих 1 та 2 груп - у 1,3 та 1,7 раза (р<0,05), у хворих 3 та 4 груп - у 2,2 та 2,9 раза (р<0,05), порівняно з ПЗО (p<0,05). Вміст $\mathrm{H}_{2} \mathrm{~S}$ вірогідно знижувався із зростанням стадії ХОЗЛ та за коморбідності з НАСГ. Встановлені кореляційні взаємозв'язки між вмістом $\mathrm{H}_{2} \mathrm{~S}$ та показниками активності цитолізу гепатоцитів (АлАТ: $\ulcorner=-0,63-0,66$, p<0,05), бронхообструкції (ОФВ $: r=0,69, p<0,05)$, гіперліпідемії $(r=-0,52-0,61, p<0,05)$, гіперпродукції компонентів сполучної тканини (білковозв'язаний оксипролін, глікозаміноглікани, фібронектин, гексозаміни, сіалові кислоти), які свідчать про фіброзування органів ( $r=-0,65-0,71, p<0,05)$, протеоліз ( $r=-0,48-0,56, p<0,05)$, дисфункцію ендотелію (монооксид нітрогену, гомоцистеїн $(r=-0,55-0,69, p<0,05)$ вказують на роль дефіциту $\mathrm{H}_{2} \mathrm{~S}$ у механізмах взаємообтяження коморбідних захворювань.

Висновок. Дефіцит гідрогену сульфіду в крові вірогідно впливає на механізми прогресування ХОЗЛ та НАСГ на тлі ожиріння. Такий висновок зроблено на підставі дослідження вмісту білкових та вуглеводно-білкових компонентів позаклітинного матриксу та протеїназоінгібіторної системи, ліпідного профілю крові, функціонального стану ендотелію.

КлючОВІ СлОВА: хронічне обструктивне захворювання легень; неалкогольний стеатогепатит; ожиріння.

Вступ. Неухильне зростання частоти випадків коморбідного перебігу хронічного обструктивного захворювання легень (ХОЗЛ) та неалкогольного стеатогепатиту (НАСГ) на тлі ожиріння у осіб працездатного віку в Україні та у світі $[1,2,3]$ зумовлює потребу в проведенні досліджень механізмів взаємообтяження та пошуку нових чинників патогенезу прогресування даної коморбідної патології. На роль гідрогену сульфіду $\left(\mathrm{H}_{2} \mathrm{~S}\right)$ у розвитку фіброзу звернули увагу лише нещодавно [4-7]. Дослідження показали, що $\mathrm{H}_{2} \mathrm{~S}$ дозозалежно впливає на розвиток фіброзу в легенях, печінці, нирках і міокарді $[4,6,8]$. Результати досліджень демонструють, що процеси фіброзування органів у сильній взаємозалежності корелюють з порушенням ендогенного синтезу $\mathrm{H}_{2} \mathrm{~S}$, зниженням активності $\mathrm{H}_{2} \mathrm{~S}$-генеруючих ферментів у плазмі крові і безпосередньо в тканинах [5-7]. Ферменти, які забезпечують ендогенний синтез $\mathrm{H}_{2} \mathrm{~S}$ (цистатіонін $\beta$-синтаза (CBS), цистатіонін $ү$-ліаза (CSE)), присутні в печінці та легенях [4, 7]. $\mathrm{H}_{2} \mathrm{~S}$ генерується шляхом транссульфурування з L-цистеїну і гомоцистеїну [5]. Крім того, 3-меркаптопіруват сульфуртрансфераза (МСТ) також може каталізувати утворення $\mathrm{H}_{2} \mathrm{~S}$ разом із цистеїнамінотрансферазою $[5,7]$.
Фіброз печінки - це динамічний процес, що виникає у відповідь на різні стимули і призводить до руйнування архітектоніки паренхіми печінки з подальшим надмірним відкладанням компонентів позаклітинного матриксу (ПКМ), формуванням фіброзної тканини та патологічної регенерації із формуванням цирозу [2]. У хворих на цироз печінки встановлено істотне гальмування експресії / активності CBS і CSE та зниження рівнів $\mathrm{H}_{2} \mathrm{~S}$ у плазмі [7]. Розвиток фіброзу легень $\epsilon$ наслідком ХОЗЛ, зумовленої впливом різних факторів, таких як органічні та неорганічні частки, хімічні речовини, іонізуюче випромінювання та інфекції [2, 8]. Його кінцевою стадією $\epsilon$ формування сотової (стільникової) легені - грубої деформації легеневого малюнка із заміщенням надмірно синтезованою сполучною тканиною легеневої паренхіми [2]. Ферменти, що виробляють $\mathrm{H}_{2} \mathrm{~S}$, (CSE, CBS та/або MST), експресуються в легенях людини і тварин [4], а фізіологічна концентрація $\mathrm{H}_{2} \mathrm{~S}$ у здорових людей становить від 10 до 300 мкмоль/л [8]. Зміна активності ферментів, що виробляють $\mathrm{H}_{2} \mathrm{~S}$, та ендогенні рівні $\mathrm{H}_{2} \mathrm{~S}$ пов'язані з розвитком легеневого фіброзу. Це доведено в дослідженнях на патологічних моделях блідоміцин (BLM)-індукованого легеневого фіброзу, які показали, що вміст $\mathrm{H}_{2} \mathrm{~S}$ у 
Огляди літератури, оригінальні дослідження, погляд на проблему, ювілеї

плазмі та швидкість вироблення $\mathrm{H}_{2} \mathrm{~S}$ у легеневій тканині в експериментальних групах знижувалась на $44 \%$ та 27 \% відповідно на 7-й день. Ці результати можна пов'язати з компенсаторним механізмом зменшення $\mathrm{H}_{2} \mathrm{~S}$ в організмі $[6,8]$. Вміст гідроксипроліну в легенях, як маркер осадження колагену, зростав на 43 \% у групі лікування BLM на 7-й день і на $100 \%$ на 28-й день, разом із гістологічними змінами інфільтрації запальних клітин, проліферації фібробластів та осадженням колагену, тоді як внутрішньочеревне введення гідросульфіду натрію - донатора $\mathrm{H}_{2} \mathrm{~S}$ (NaHS, 1,4 та 7 мкмоль / кг маси тіла, відповідно) двічі на добу зменшило вміст гідроксипроліну і нейтралізувало тяжкість фіброзу легені [6]. Згідно з вищезгаданими дослідженнями, екзогенний $\mathrm{H}_{2} \mathrm{~S}$ (NaHS) вважається протективним чинником проти розвитку фіброзу легень при порівняно низькій дозі від 1,4 мкмоль / кг маси тіла 2 раза на день до 28 мкмоль / кг один раз на день [4-8]. Однак, висока концентрація $\mathrm{H}_{2} \mathrm{~S}$ (>500 ppm) може викликати набряк легень і, зрештою, теж призвести до хронічного запалення та легеневого фіброзу $[6,8]$. Комплексні дослідження гомеостазу $\mathrm{H}_{2} \mathrm{~S}$ можуть відкрити нові механізми взаємообтяження ХОЗЛ та НАСГ. На підставі встановлених даних стане можливим обґрунтування шляхів корекції встановлених розладів.

Мета - встановити роль $\mathrm{H}_{2} \mathrm{~S}$ у механізмах прогресування ХОЗЛ та НАСГ на тлі ожиріння.

Матеріал і методи дослідження. Обстежено 100 хворих на ХОЗЛ, у тому числі 49 із НАСГ та ожирінням I ступеня: 1 група - 28 пацієнтів із ХОЗЛ (2B GOLD); 2 група - 23 хворих на ХОЗЛ (3С, D); 3 група - 25 пацієнтів із ХОЗЛ (2В) із НАСГ; 4 група - 24 хворих на ХОЗЛ (3С, D) із НАСГ. Середній вік пацієнтів склав $(47,3 \pm 3,1)$ років. Контрольну групу склали 20 практично здорових осіб (ПЗО) відповідного віку та статі.

Вміст $\mathrm{H}_{2} \mathrm{~S}$ у крові визначали спектрофотометричним методом [4]. Зміни метаболізму компонентів позаклітинного матриксу визначали за вмістом у крові вільного оксипроліну (ВОП) за С. С. Тетянець (1985) та білковозв'язаного оксипроліну (БЗОП) за М. С. Осадчуком (1979), гексозамінів (ГА) за О. Г. Архіповою (1988), серомукоїдів (СМ), сіалових кислот (СК) - за допомогою наборів фірми „Даниш Ltd” (м. Львів), церулоплазміну (ЦРП) за методом М. Р. Ревіна (1976). Стан протеолітичної активності плазми крові вивчали за сумарною активністю протеїназ сироватки крові за М. Кунітцом (1975), інтенсивністю лізису низькомолекулярних білків (азоальбуміну), високомолекулярних білків (азоказеїну) та колагену (лізис азоколу) за допомогою реактивів фірми „Даниш Ltd" (Львів). Стан протеїназо-інгібіторної системи вивчали за вмістом у сироватці крові $a_{2}-\mathrm{MГ,} \mathrm{вміс-}$ том в плазмі крові $a_{1}$-ІП („Даниш Ltd”, Львів). Ліпідний спектр крові вивчали за вмістом загальних ліпідів, загального холестеролу (ЗХC), триацилгліцеролів (ТГ), XС ліпопротеїнів низької щільності (ЛПНЩ), ХС ліпопротеїнів високої щільності (ЛПВЩ), із обчисленням індексу атерогенності (IA). Функціональний стан ендотелію вивчали за вмістом у крові метаболітів монооксиду нітрогену (NO) (нітритів/нітратів), ендотеліну-1, методом IФA (ELISA).

Статистичну обробку результатів проводили із використанням параметричних та непараметричних методів варіаційної статистики. Нормальність розподілу перевіряли за допомогою теста Шапіро-Уїлка та методом прямої візуальної оцінки гістограм розподілу власних значень. При непараметричному розподілі дані представлені у вигляді медіани (Ме) як міри положення, верхнього $\left(\mathrm{Q}_{75}\right)$ і нижнього квартилів $\left(\mathrm{Q}_{25}\right)$ у якості міри розсіювання. Для порівнянь даних, які мали нормальний характер розподілу, використовували параметричні тести з оцінкою t-критерію Стьюдента, F-критерію Фішера. Для оцінки міри залежності між змінними використовували кореляційний аналіз за Пірсоном при параметричному розподілі та коефіцієнт рангової кореляції Спірмена. Для порівняння дискретних величин у незалежних групах застосовували критерій $x_{2}$ максимальної правдоподібності (log-likelhood) (MП $\mathrm{x}_{2}$ ), для порівняння пар дискретних величин використовували розрахунок модифікації точного критерію Фішера (mid-p).

Дослідження проведені з дотриманням основних положень GСP (1996р.), Конвенції Ради Європи про права людини та біомедицину (від 04.04.1997р.), Гельсінської декларації Всесвітньої медичної асоціації про етичні принципи проведення наукових медичних досліджень за участю людини (1964-2013 рр.), наказів МО3 України № 690 від 23.09.2009 р., № 616 від 03.08.2012 р.

Результати й обговорення. Аналізуючи ступінь бронхообструктивного синдрому в групах порівняння ми встановили, що у хворих на ХОЗЛ за коморбідності з НАСГ ступінь зниження ОФВ 1 нижчий, ніж за ізольованого перебігу (табл. 1): відповідно, зниження у 1 групі хворих склало 1,4 раза, порівняно з ПЗО (р<0,05), у 3 групі - у 1,7 раза $(p<0,05)$. У хворих 2 та 4 груп - відповідно у 2,4 та 2,8 раза ( $<<0,05)$. Таким чином, коморбідність з НАСГ у хворих на ХОЗЛ сприяє посиленню обструкції бронхів. Слід також зазначити, що із зростанням стадії ХОЗЛ зростає активність НАСГ: відповідно у хворих 3 та 4 груп - активність АлАТ перевищила дані у ПЗО у 2,2 та 2,8 раза ( $<<0,05)$, що свідчить про несприятливий вплив ХОЗЛ на перебіг НАСГ. 
Огляди літератури, оригінальні дослідження, погляд на проблему, ювілеї

Вміст у крові $\mathrm{H}_{2} \mathrm{~S}$ у хворих 1-4 груп був знижений: відповідно у $1,3,1,5,1,7$ та 2,6 раза $(p<0,05)$, порівняно з показником у ПзО. Аналіз інтенсивності фіброзувальних реакцій у хворих на ХОЗЛ, залежно від наявності коморбідного НАСГ, вказує на вірогідне збільшення вмісту в крові БзОП у хворих усіх груп: у 1 групі - 1,5 раза, порівняно з Пзо $(p<0,05)$, у 2 групі - у 1,8 раза $(p<0,05)$, у 3 групі - y 2,0 раза $(p<0,05)$, у 4 групі - у 2,4 раза $(p<0,05)$. Водночас, показник вмісту в крові ВОП (табл. 1), який $\epsilon$ біохімічним маркером катаболізму колагену, у хворих на ХОЗЛ 1 групи був вищий від показника у
ПЗО у 1,2 раза $(p<0,05)$, у хворих 2 групи - у 1,4 раза $(p<0,05)$, що вказує на паралельне підвищення деградації колагену на тлі його підвищеного синтезу. За коморбідності з НАСГ активність деградації колагену була ще більш інтенсивною: відповідно у хворих 3 та 4 груп - у 1,5 та 1,7 раза $(p<0,05)$ (див. табл. 1). Ухворих усіх груп було виявлено вірогідне зростання показників КЛА крові, інтенсивність якої перевищила показник у ПЗО у 1 групі на 10,7\% $(p<0,05)$, у 2 групі - на $16,7 \%(p<0,05)$, у 3 та 4 групах - більш інтенсивно: на $34,5 \%$ та 61,9 \% із наявністю вірогідної міжгрупової різниці $(p<0,05)$.

Таблиця 1. Показники стану функції зовнішнього дихання, вмісту $\mathrm{H}_{2} \mathrm{~S}$, компонентів сполучної тканини, протеолізу, функціонального стану ендотелію та їх регуляції у хворих на хронічне обструктивне захворювання легень та неалкогольний стеатогепатит

\begin{tabular}{|c|c|c|c|c|c|}
\hline \multirow{2}{*}{$\begin{array}{c}\text { Показники, од. } \\
\text { вимірювання }\end{array}$} & \multirow{2}{*}{$\begin{array}{c}\Pi 30 \\
(n=20)\end{array}$} & \multicolumn{4}{|c|}{ Групи обстежених хворих } \\
\hline & & $\begin{array}{c}1 \text { група } \\
(n=28)\end{array}$ & $\begin{array}{c}2 \text { група } \\
(n=23)\end{array}$ & $\begin{array}{c}3 \text { група } \\
(\mathrm{n}=25)\end{array}$ & $\begin{array}{c}4 \text { група } \\
(n=24)\end{array}$ \\
\hline OФВ1, \% & $98,2 \pm 2,1$ & $67,2 \pm 1,4$ * & $41,5 \pm 1,1 * / * *$ & $58,2 \pm 1,3 * / * * / * *$ & $35,7 \pm 1,2 * / * * / * * * / \#$ \\
\hline $\begin{array}{l}\text { АлАТ, мкмоль/ } \\
\text { годхл }\end{array}$ & $0,42 \pm 0,01$ & $0,43 \pm 0,01$ & $0,45 \pm 0,01$ & $0,93 \pm 0,02 * / * * / * * *$ & $1,16 \pm 0,03 * / * * / * * * / \#$ \\
\hline $\mathrm{H}_{2} \mathrm{~S}$, мкмоль/л & $75,3 \pm 3,2$ & $59,21 \pm 1,40$ * & $51,52 \pm 1,32 * / * *$ & $43,24 \pm 1,53 * / * * / * *$ & $27,8 \pm 1,38 * / * * / * * * / \#$ \\
\hline БЗОП, мкмоль/л & $41,48 \pm 3,72$ & $61,88 \pm 2,54^{*}$ & $73,23 \pm 2,96 * / * *$ & $84,21 \pm 3,65 * / * *$ & $97,38 \pm 3,42 * / * * / * * *$ \\
\hline ВОП, мкмоль/л & $12,39 \pm 0,34$ & $15,27 \pm 0,43$ * & $17,46 \pm 0,57 * / * *$ & $18,13 \pm 0,48 * / * *$ & $21,47 \pm 0,31 * / * * / * * * / \#$ \\
\hline ГА, ммоль/л & $5,54 \pm 0,02$ & $6,23 \pm 0,09 *$ & $6,47 \pm 0,12 * / * *$ & $7,33 \pm 0,15 * / * * / * * *$ & $7,83 \pm 0,18 * / * * / * * * / \#$ \\
\hline СК, ммоль/л & $1,92 \pm 0,02$ & $2,43 \pm 0,05^{*}$ & $2,81 \pm 0,07 * / * *$ & $3,37 \pm 0,11 * / * * / * * *$ & $3,79 \pm 0,08 * / * * / * * * / \#$ \\
\hline КЛА, у.о. & $0,84 \pm 0,01$ & $0,93 \pm 0,01$ * & $0,98 \pm 0,01 * / * *$ & $1,13 \pm 0,01 * / * * / * * *$ & $1,36 \pm 0,01 * / * * / * * * / \#$ \\
\hline ЦП, ммоль/л & $12,63 \pm 0,12$ & $16,32 \pm 0,37^{*}$ & $21,42 \pm 1,09 * / * *$ & $24,38 \pm 1,17 * / * * / * * *$ & $28,52 \pm 1,24 * / * * / * * * / \#$ \\
\hline $\mathrm{a}_{2}$-МГ, ммоль/л & $2,35 \pm 0,12$ & $3,43 \pm 0,13^{*}$ & $3,95 \pm 0,10 * / * *$ & $3,77 \pm 0,11 * / * *$ & $4,06 \pm 0,12 * / * *$ \\
\hline $\begin{array}{l}\text { Лізис АA, E440/ } \\
\text { млхгод }\end{array}$ & $2,41 \pm 0,02$ & $3,63 \pm 0,05$ * & $3,94 \pm 0,03 * / * *$ & $4,25 \pm 0,08 * / * * / * * *$ & $4,57 \pm 0,09 * / * * / * * * / \#$ \\
\hline NO, мкмоль/л & $17,62 \pm 1,43$ & $19,58 \pm 0,23$ * & $23,18 \pm 0,31 * / * *$ & $24,21 \pm 0,57 * / * *$ & $25,19 \pm 0,35 * / * * / * * *$ \\
\hline ET-1, пмоль/л & $6,01 \pm 0,94$ & $8,27 \pm 1,02$ * & $11,50 \pm 0,56 * / * *$ & $12,15 \pm 1,07 * / * *$ & $14,67 \pm 0,98 * / * * / * * *$ \\
\hline Заг. ХС, ммоль/л & $4,72 \pm 0,11$ & $5,23 \pm 0,13 *$ & $5,49 \pm 0,09$ * & $6,65 \pm 0,13 * / * * / * * *$ & $6,79 \pm 0,19 * / * * / * * *$ \\
\hline ТГ, ммоль/л & $1,47 \pm 0,03$ & $2,12 \pm 0,03$ * & $2,43 \pm 0,02 * / * *$ & $3,25 \pm 0,05 * / * * / * * *$ & $3,14 \pm 0,01 * / * * / * * *$ \\
\hline
\end{tabular}

Примітки: * - зміни вірогідні у порівнянні з показником у ПзО (р<0,05); ** - зміни вірогідні при порівнянні показників у хворих 1 групи (р<0,05); *** - зміни вірогідні при порівнянні показників у хворих 2 групи (р<0,05); \# - зміни вірогідні при порівнянні показників у хворих 3 групи $(p<0,05)$.

Інтенсивність лізису низькомолекулярних білків у хворих усіх груп також була вищою від показника у ПЗО: відповідно у 1,5-1,9 раза $(p<0,05)$, i зростала із зростанням стадіїХОЗЛ і при приєднанні НАСГ. Ми встановили вірогідне зростання вмісту в крові $\mathrm{a}_{2}$-МГ (див. табл. 1) із зростанням стадії ХОЗЛ: у хворих 2 групи (у 1,7 раза проти 1,5 у хворих 1 групи, $><0,05)$, однак ці показники при коморбідності з НАСГ не змінювались $(p>0,05)$. Показники вмісту церулоплазміну вказують на його вірогідне підвищення у хворих усіх груп спостереження $(p<0,05)$ із вірогідним переважанням у хворих 4 групи (у 2,3 раза проти 1,9 раза у 3 групі, у 1,3 раза -у 1 групі, p<0,05) (див. табл. 1). Показники функціонального стану ендотелію вказують на його дисфункцію: вміст у крові NO був вірогідно підвищений у хворих 1 та 2 груп: відповідно на $11,3 \%$ та $31,7 \%(p<0,05)$, тоді як у хворих 3 та 4 груп - зріс на 37,6 \% та 41,7 \% (p<0,05). При цьому вміст у крові ЕТ-1 перевищив показник у ПзО відповідно у 1,4-2,4 раза $(p<0,05)$, що вказує на істотне переважання вазоконстрикторів, що сприяє гіпоксії, ішемії паренхіми печінки та легень, і $\in$ додатковими факторами пошкодження внаслідок кисневого та енергетичного голодування [9-12]. Причиною дисбалансу маркерів функціонального стану ендотелію стала, на наш погляд, гіпер- та дисліпідемія (див. табл. 1). Так, у хворих на ХОЗЛ встановлено вірогідне зростання в крові вмісту загального XС-у 1 та 2 групах - на 11,3 \% та 16,8 \% 
Огляди літератури, оригінальні дослідження, погляд на проблему, ювілеї відповідно ( $p<0,05)$. За коморбідності з НАСГ вміст ХС у крові зріс істотніше: у хворих 3 та 4 груп - на $41,5 \%$ та 44,5\% (p<0,05). Вміст ТГ у крові хворих на ХОЗЛ був істотно підвищений: у 1,4 та 1,7 раза ( $p<0,05)$, а за коморбідності із НАСГ - ще значніше: у 2,1-2,2 раза $(p<0,05)$.

Встановлені кореляційні взаємозв'язки між вмістом $\mathrm{H}_{2} \mathrm{~S}$ та показниками активності цитолізу гепатоцитів (АлАТ: $r=-0,63-0,66, p<0,05)$, бронхообструкції (ОФВ1: $\ulcorner=0,69, p<0,05)$, гіперліпідемії ( $r=-0,52-0,61, p<0,05)$, гіперпродукції компонентів сполучної тканини (білковозв'язаний оксипролін, глікозаміноглікани, сіалові кислоти), які свідчать про фіброзування органів ( $r=-0,65-0,71, p<0,05)$, протеолізу ( $r=-0,48-0,56, p<0,05)$, дисфункції ендотелію (монооксид нітрогену, ЕТ-1 ( $r=-0,55-0,69$, $p<0,05)$, вмістом XС та ТГ в крові ( $r=-0,61-0,65$, $\mathrm{p}<0,05)$ вказують на роль дефіциту H2S у механізмах взаємообтяження коморбідних захворювань. Отримані дані свідчать про те, що у хворих на ХОЗЛ із фоновим НАСГ, що виник на тлі ожиріння, встановлено істотне підвищення синтезу колагену та глікопротеїнів, що призводить до прогресуючого фіброзування легень та печінки із порушенням їх функцій. Цьому сприяло порушення гомеостазу $\mathrm{H}_{2} \mathrm{~S}$, що підтверджують дані кореляційного аналізу. За умов дефіциту $\mathrm{H}_{2} \mathrm{~S}$ i коморбідності ХОЗЛ та НАСГ активуються і синтез, і резорбція колагену, але процеси анаболізму переважають внаслідок активації системи фібробластів, із істотнішою гіперпродукцією гострофазових білків, фібронектину, ГА вищим ступенем гіпер- та дисліпідемії $(p<0,05)$, вищим ступенем дисфункції ендотелію (гіпепродукція NO та ET-1 $(p<0,05))$. Протективна роль $\mathrm{H}_{2} \mathrm{~S}$ у прогресуванні ХОЗЛ та жирової хвороби печінки пояснюється його антиоксидантним, антиапоптотичним, протизапальним, вазодилятаційним та антигіпоксантним ефектами, здатністю стимулювати ангіогенез, знижувати вміст проатерогенних ліпопротеїнів у крові та гальмувати активність фібробластів [8, 13-15].

Висновки. 1. У хворих на ХОЗЛ та НАСГ, що виник на тлі ожиріння, встановлено підвищення синтезу колагену та глікопротеїнів, яке супроводжується неефективною резорбцією новоутвореного колагену на тлі істотної активації інгібіторів протеїназ ( $a_{2}-\mathrm{M \Gamma )}$, що супроводжується гіперпродукцією монооксиду нітрогену, ендотеліну-1, гіперліпідемією, дефіцитом ліберації гідрогену сульфіду.

2. Дефіцит гідрогену сульфіду в крові вірогідно впливає на механізми прогресування ХОЗЛ на НАСГ на тлі ожиріння на підставі дослідження вмісту білкових та вуглеводно-білкових компонентів позаклітинного матриксу та протеїназо-інгібіторної системи, ліпідного профілю крові, функціонального стану ендотелію.

Перспективи подальших досліджень. Планується проведення комплексного дослідження гоместазу $\mathrm{H}_{2} \mathrm{~S}$, яке дасть можливість відкрити нові механізми взаємообтяження ХОЗЛ та НАСГ і обґрунтувати шляхи корекції встановлених розладів.

\section{ЛІТЕРАТУРА}

1. Бабак О. Я. Стан сироваткових маркерів фіброзу печінки при неалкогольній жировій хворобі печінки / О. Я. Бабак, О. В. Колеснікова / Сучасна гастроентеролог. - 2008. - № 3 (41). - С. 9-13.

2. Неалкогольна жирова хвороба печінки, ожиріння та хронічне обструктивне захворювання легень: чинники ризику та механізми взаємообтяження та прогресування / О. С. Хухліна, А. А. Антонів, О.Є. Мандрик, О.Є. Гринюк // Неалкогольна жирова хвороба печінки та коморбідні стани: особливості патогенезу, клініки, діагностики, лікування: кол. моног. - Чернівці, 2018. - С. 58-61. ISBN 978-966-697-546-4

3. A position statement on NAFLD/NASH based on the EASL 2009 special conference / V. Ratziu, S. Bellentani, H. Cortez-Pinto [et al.] // Journal of Hepatology. - 2010. Vol. 53, No. 2. - P. 372-384.

4. Hydrogen sulfide suppresses migration, proliferation and myofibroblast transdifferentiation of human lung fibroblasts / L. P. Fang, Q. Lin, C. S. Tang, X. M. Liu // Pulmonary Pharmacology and Therapeutics. -2009. - No. 22 (6).P. 554-561.

5. Guo C. Hydrogen sulfide protected gastric epithelial cell from ischemia/reperfusion injury by Keap1 s-sulfhydration, MAPK dependent anti-apoptosis and NF-KB dependent anti-inflammation pathway / F. Liang, W. Shah Masood, X. Yan // European Journal of Pharmacology. 2014. - No. 725 (1). - P. 70-78.

6. Hydrogen sulfide attenuates the pathogenesis of pulmonary fibrosis induced by bleomycin in rats / L. Fang, H. Li, C. Tang // Physiol. Pharmacol. - 2009. - No. 87 (7). P. 531-538. doi: 10.1139/y09-039.

7. Protective effects of hydrogen sulfide on oxidative stress and fibrosis in hepatic stellate cells / H. N. Fan, H. J. Wang, C. R. Yang-Dan [et al.] // Mol. Med. Rep. -2013. No. 7 (1). - P. 247-253.

8. Serum hydrogen sulfide as a novel marker predicting bacterial involvement in patients with community-acquired lower respiratory tract infections / Y. H. Chen, W. Z. Yao, J. Z. Gao [et al.] // Respirology. - 2009. - Vol. 14 (5). P. 746-752.

9. Absence of ghrelin protects against early-onset obesity / K. E. Wortley, J. P. del Rincon, J. D. Murray [et 
Огляди літератури, оригінальні дослідження, погляд на проблему, ювілеї

al.] // J. Clin. Invest. - 2005. - Vol.115, No. 12. P. 3573-3578.

10. Adams L. A. Nonalcoholic fatty liver disease / L. A. Adams, K. D. Lindor // Ann. Epidemiol. -2007. - Vol.17, No. 11. - P. 863-869.

11. Chalasani N. The diagnosis and management of non-alcoholic fatty liver disease: Practice guideline by the American Association for the Study of Liver Diseases, American College of Gastroenterology, and the American Gastroenterological Association / N. Chalasani, Z. Younossi, J. E. Lavine [et al.] // Am. J. Gastroenterol. - 2012. No. 107 (6). - P. 811-826.

12. Clinical and pathogenetic features of nonalcoholic steatohepatitis for comorbidity with bronchial asthma on the background of obesity / O. S. Khukhlina, O. Y. Нry- niuk, S. V. Kovalenko [et al.] // Wiadomości Lekarskie. 2018. - tom LXXI. - nr 2 cz I. - Str.376

13. Comparison of NAFLD fibrosis score and BARD score in predicting fibrosis in nonalcoholic fatty liver disease / G. Ruffillo, E. Fassio, E. Alvarez [et al.] // J. Hepatol. 2011. - Vol. 54, No. 1. - P. 160-163.

14. Diagnosis of fibrosis and cirrhosis using liver stiffness measurement in nonalcoholic fatty liver disease / V. W. Wong, J. Vergniol, G. L. Wong [et al.] // Hepatology. 2010. - Vol. 51, No. 2. - P. 454-462.

15. Independent predictors of fibrosis in patients with nonalcoholic fatty liver disease / N. Hossain, A. Afendy, M. Stepanova [et al.] // Clin. Gastroenterol. Hepatol. - 2009. Vol. 7, No. 11. - P. 1224-1229.

\section{REFERENCES}

1. Babak, O.Ya., \& Kolesnikova, O.V. (2008). Stan syrovatkovykh markeriv fibrozu pechinky pry nealkoholnii zhyrovii khvorobi pechinky [Status of serum liver fibrosis markers in non-alcoholic fatty liver disease]. Suchasna hastroenterolohiia - Modern Gastroenterology, 3 (41), 9-13 [in Ukrainian].

2. Hryniuk, O.Ye., Khukhlina, O.S., Antoniv, A.A., \& Mandryk, O.Ye. (2018). Nealkoholna zhyrova khvoroba pechinky, ozhyrinnia ta khronichne obstruktyvne zakhvoriuvannia lehen: chynnyky ryzyku ta mekhanizmy vzaiemoobtiazhennia ta prohresuvannia [Non-alcoholic fatty liver disease, obesity and chronic obstructive pulmonary disease: risk factors and mechanisms of interweaving and progression]. Nealkoholna zhyrova khvoroba pechinky ta komorbidni stany: osoblyvosti patohenezu, kliniky, diahnostyky, likuvannia: kol. monoh. Non-alcoholic fatty liver disease and comorbid conditions: peculiarities of pathogenesis, clinics, diagnostics, treatment. Chernivtsi [in Ukrainian].

3. Ratziu, V., Bellentani, S., \& Cortez-Pinto, H. (2010). A position statement on NAFLD/NASH based on the EASL 2009 special conference. Journal of Hepatology, 53 (2), 372-384.

4. Fang, L.P., Lin, Q., Tang, C.S, \& Liu, X.M. (2009). Hydrogen sulfide suppresses migration, proliferation and myofibroblast transdifferentiation of human lung fibroblasts. Pulmonary Pharmacology and Therapeutics, 22 (6), 554-561.

5. Guo, C., Liang, F., Shah Masood, W., \& Yan, X. (2014). Hydrogen sulfide protected gastric epithelial cell from ischemia/reperfusion injury by Keap1 s-sulfhydration, MAPK dependent anti-apoptosis and NF-KB dependent anti-inflammation pathway. European Journal of Pharmacology, 725 (1), 70-78.

6. Fang, L., Li, H., \& Tang, C. (2009). Hydrogen sulfide attenuates the pathogenesis of pulmonary fibrosis induced by bleomycin in rats. Physiol. Pharmacol., 87 (7), 531538. doi: 10.1139/y09-039.

7. Fan, H.N., Wang, H.J., \& Yang-Dan, C.R. (2013). Protective effects of hydrogen sulfide on oxidative stress and fibrosis in hepatic stellate cells. Mol. Med. Rep. 7 (1), 247253.

8. Chen, Y.H., Yao, W.Z., \& Gao, J.Z. (2009). Serum hydrogen sulfide as a novel marker predicting bacterial involvement in patients with community-acquired lower respiratory tract infections. Respirology, 14 (5), 746-752.

9. Wortley, K.E., del Rincon, J.P., \& Murray, J.D. (2005). Absence of ghrelin protects against early-onset obesity. J. Clin. Invest., 115 (12), 3573-3578.

10. Adams, L.A., \& Lindor, K.D. (2007). Nonalcoholic fatty liver disease. Ann. Epidemiol., 17 (11), 863-869.

11. Chalasani, N., Younossi, Z., \& Lavine, J.E. (2012). The diagnosis and management of non-alcoholic fatty liver disease: Practice guideline by the American Association for the Study of Liver Diseases, American College of Gastroenterology, and the American Gastroenterological Association. Am. J. Gastroenterol., 107 (6), 811-826.

12. Khukhlina, O.S., Hryniuk, O.Y., \& Kovalenko, S.V. (2018). Clinical and pathogenetic features of nonalcoholic steatohepatitis for comorbidity with bronchial asthma on the background of obesity. Wiadomości Lekarskie, LXXI, 376.

13. Ruffillo, G., Fassio, E., \& Alvarez, E. (2011). Comparison of NAFLD fibrosis score and BARD score in predicting fibrosis in nonalcoholic fatty liver disease. J. Hepatol., $54(1), 160-163$

14. Wong, V.W., Vergniol, J., \& Wong, G.L. (2010). Diagnosis of fibrosis and cirrhosis using liver stiffness measurement in nonalcoholic fatty liver disease. Hepatology, 51 (2), 454-462.

15. Hossain, N., Afendy A., \& Stepanova, M. (2009). Independent predictors of fibrosis in patients with nonalcoholic fatty liver disease. Clin. Gastroenterol. Hepatol., 7 (11), 1224-1229. 


\title{
Огляди літератури, оригінальні дослідження, погляд на проблему, ювілеї \\ ВЛИЯНИЕ ДЕФИЦИТА ГИДРОГЕН СУЛЬФИДА НА ПАТОГЕНЕТИЧЕСКИЕ МЕХАНИЗМЫ ПРОГРЕССИРОВАНИЯ ХРОНИЧЕСКОЙ ОБСТРУКТИВНОЙ БОЛЕЗНИ ЛЕГКИХ И НЕАЛКОГОЛЬНОГО СТЕАТОГЕПАТИТА НА ФОНЕ ОЖИРЕНИЯ
}

\author{
๑О. С. Хухлина, О. Е. Гринюк, О. Е. Мандрик, О. В. Каушанская, В. С. Смандич \\ ВГУз Украины «Буковинский государственный медицинский университет»
}

РЕЗЮМЕ. Комплексные исследования гомеостаза гидроген сульфида $\left(\mathrm{H}_{2} \mathrm{~S}\right)$ могут открыть новые механизмы взаимообременения хронического обструктивного заболевания легких (ХОБЛ) и неалкогольного стеатогепатита (НАСГ).

Цель - установить роль $\mathrm{H}_{2} \mathrm{~S}$ в механизмах прогрессирования ХОБЛ и НАСГ на фоне ожирения.

Материал и методы. Обследовано 100 больных ХОБЛ, в том числе 49 с НАСГ и ожирением I степени: 1 группа - 28 пациентов с ХОБЛ (2B GOLD); 2 группа - 23 больных ХОБЛ (3C, D); 3 группа - 25 пациентов с ХОБЛ (2B) с НАСГ; 4 группа - 24 больных ХОБЛ (3С, D) с НАСГ; контрольная группа - 20 практически здоровых лиц (ПЗЛ).

Результаты. Содержание в крови $\mathrm{H}_{2}$ S у ПзЛ составило $(75,3 \pm 3,2)$ мкмоль/л. У больных всех групп содержание в крови $\mathrm{H}_{2}$ S было снижено: у больных 1 и 2 групп - в 1,3 и 1,7 раза (р<0,05), у больных 3 и 4 групп - в 2,2 и 2,9 раза $(p<0,05)$, по сравнению с ПЗЛ ( $<<0,05)$. Содержание $\mathrm{H}_{2}$ S достоверно снижалось с ростом стадии ХОБЛ и при коморбидности с НАСГ. Установлены корреляционные взаимосвязи между содержанием $\mathrm{H}_{2} \mathrm{~S}$ и показателями активности цитолиза гепатоцитов (АЛТ: $\ulcorner=-0,63-0,66, p<0,05), 6 р о н х о о б с т р у к ц и и ~\left(О Ф B_{1}: ~ г=0,69, p<0,05\right)$, гиперлипидемии $(\ulcorner=-0,52-0,61, p<0,05)$, гиперпродукции компонентов соединительной ткани (белковосвязанный оксипролин, гликозаминогликаны, фибронектин, гексозамины, сиаловые кислоты), которые свидетельствуют о фиброзировании органов ( $r=-0,65-0,71, p<0,05)$, протеолиза $(r=-0,48-0,56, p<0,05)$, дисфункции эндотелия (монооксид азота, гомоцистеин $(r=-0,55-0,69, p<0,05)$ указывают на роль дефицита $\mathrm{H}_{2} \mathrm{~S}$ в механизмах взаимоотягощающих коморбидных заболеваний.

Вывод. Дефицит гидроген сульфида в крови достоверно влияет на механизмы прогрессирования ХОБЛ и НАСГ на фоне ожирения. Этот вывод сделан на основании исследования содержания белковых и углеводнобелковых компонентов внеклеточного матрикса и протеиназоингибиторной системы, липидного профиля крови, функционального состояния эндотелия.

КЛЮчЕВЫЕ СЛОВА: хроническое обструктивне заболевание легких; неалкогольной стеатогепатит; ожирение.

\section{THE INFLUENCE OF HYDROGEN SULFIDE DEFICIENCY ON PATHOGENETIC MECHANISMS FOR PROGRESSION OF CHRONIC OBSTRUCTIVE PULMONARY DISEASE AND NON-ALCOHOLIC STEATOHEPATITIS AGAINST THE BACKGROUND OF OBESITY}

\author{
๑O. S. Khukhlina, O. Ye. Hryniuk, O. Ye. Mandryk, O. V. Kaushanska, V. S. Smandych \\ Bukovyna State Medical University
}

SUMMARY. Comprehensive studies of homeostasis of hydrogen sulfide $\left(\mathrm{H}_{2} \mathrm{~S}\right)$ may open new mechanisms of complications of chronic obstructive pulmonary disease (COPD) and nonalcoholic steatohepatitis (NASH).

The aim of the study - to establish the role of $\mathrm{H}_{2} \mathrm{~S}$ in the mechanisms of progression of COPD and NASH on the background of obesity.

Material and Methods. 100 patients with COPD were examined, including 49 with NASH and obesity of the 1st degree: group $1-28$ patients with COPD (2B GOLD). Group 2-23 patients with COPD (3C, D). Group $3-25$ patients with COPD (2B) with NASH. Group $4-24$ patients with COPD (3C, D) and NASH. Control group - 20 healthy persons (HP).

Results. The content of $\mathrm{H}_{2} \mathrm{~S}$ in blood in HP was $(75.3 \pm 3.2) \mu \mathrm{mol} / \mathrm{l}$. In patients of all groups, the content of $\mathrm{H}_{2} \mathrm{~S}$ in the blood was reduced: in patients of group 1 and $2-$ in 1.3 and 1.7 times $(p<0.05)$, in patients of group 3 and $4-$ in 2.2 and 2.9 times $(p<0.05)$ in comparison with HP $(p<0.05)$. With the increase of COPD stage and in case of NASH comorbidity the content of $\mathrm{H}_{2} \mathrm{~S}$ probably decreased. The following correlation relationships have been set: $\mathrm{H}_{2} \mathrm{~S}$ content and the hepatocyte cytolysis activity (ALT: $r=-0.63-0.66, p<0.05)$, bronchoconstriction (FEV1: $r=0.69, p<0.05$ ), hyperlipidemia $(r=-0,52-0,61$, $\mathrm{p}<0,05)$, hyperproduction of connective tissue components (protein-bound oxyproline, glycosaminoglycans, fibronectin, hexosamines, sialic acids), indicating organ fibrosis ( $r=-0.65-0.71, p<0.05)$, proteolysis $(r=-0.48-0.56$, $p<0.05)$, endothelial dysfunction (nitrogen monoxide, homocysteine $(r=-0.55-0.69, p<0.05)$ ) indicate the role of the $\mathrm{H}_{2} \mathrm{~S}$ deficiency in the mechanisms of progression of comorbid diseases.

Conclusions. The deficiency of $\mathrm{H}_{2} \mathrm{~S}$ in the blood probably affects the mechanisms of progression of COPD and NASH on the background of obesity based on the research of content of protein and carbohydrate-protein components of the extracellular matrix and proteinase-inhibitory system, lipid profile, endothelial functional status.

KEY WORDS: chronic obstructive pulmonary disease; nonalcoholic steatohepatitis; obesity. 